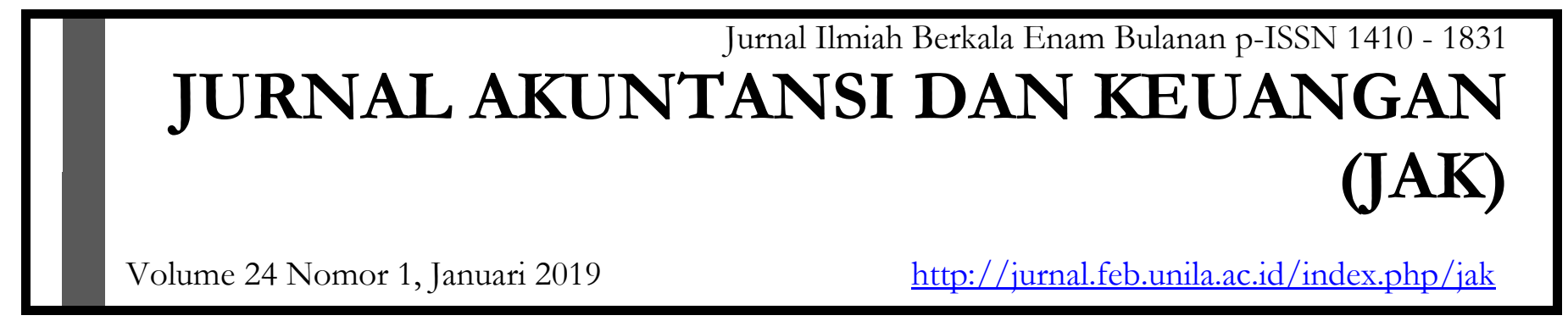

\title{
PERBANDINGAN KINERJA KEUANGAN PEMERINTAH PROPINSI DI INDONESIA
}

\section{(Studi Pada Provinsi di Jawa dan di Sumatera)}

\author{
Fadhilah Nuraini $^{1}$, Kiagus Andi ${ }^{2}$, Yunia Amelia ${ }^{3}$, Fitra Dharma ${ }^{4}$ \\ 1 Jurusan Akuntansi Fakultas Ekonomi dan Bisnis Universitas Lampung \\ 2 Jurusan Akuntansi Fakultas Ekonomi dan Bisnis Universitas Lampung \\ 3 Jurusan Akuntansi Fakultas Ekonomi dan Bisnis Universitas Lampung \\ 4 Jurusan Akuntansi Fakultas Ekonomi dan Bisnis Universitas Lampung
}

\section{Informasi Naskah}

Update Naskah:

Dikumpulkan:24 Oktober 2018

Diterima: 11 Desember 2018

Terbit/Dicetak: 29 Januari 2019

Keywords:

Comparison, Financial

Performance, Local Government

\section{Abstract}

The purpose of this study is to compare the financial performance of the provincial governments in Java and Sumatra in the 2014-2017 period and to determine the differences in the financial performance of the provincial governments in Java and Sumatra in the 2014-2017 period.The research method used is quantitative research methods. The population in this study is the report of the Realization of Regional Government Revenue and Expenditures of Provincial Governments in Indonesia in 2014-2017. The sample selection uses a purposive sampling technique that is sampling taking into account certain characteristics and criteria.The results of this study are based on the results of descriptive analysis in mind that the financial performance of provinces in Java is better than provinces in Sumatra. While the results of different tests show that there is no significant difference in the financial performance of the provincial governments in Java and Sumatra because it shows a significance value of more than 0.05 . 
Proses anggaran merupakan kesempatan yang baik untuk melakukan evaluasi, apakah pemerintah daerah melakukan tugasnya dengan efektif, efisien, dan ekonomis, atau dengan kata lain apakah pemerintah daerah melakukan "hal yang benar dengan benar". Penilaian kinerja pemerintah daerah harus mempertimbangkan dua elemen penting yang berbeda, namun sangat berkaitan erat. Pertama dan terpenting adalah apakah pemerintah daerah melakukan "hal yang benar" dalam hal pelayanan publik yang disediakan dan proyek yang dikerjakan?. Kedua adalah apakah pemerintah melakukan "sesuatu hal dengan benar" dalam arti kepatuhan dan standar efisiensi? (Halim, 2012:2).

Keberhasilan otonomi daerah tidak terlepas dari kinerja Pemerintah Daerah dalam mengelola keuangannya secara tertib, taat pada peraturan perundang-undangan, efisien, ekonomis, efektif, transparan dan bertanggung jawab. Pengelolaan keuangan daerah tersebut dilaksanakan dalam suatu sistem yang terintegrasi yang diwujudkan dalam APBD yang setiap tahun ditetapkan dengan peraturan daerah (PP 58 tahun 2005, pasal 4). Salah satu solusi untuk pemerintah daerah dalam memperbaiki segala kesalahan yang telah terjadi, Anggaran Berbasis Kinerja dapat menjadi jawabannya. Anggaran Berbasis Kinerja pada dasarnya digunakan untuk mengatasi berbagai kelemahan yang terdapat pada pendekatan anggaran tradisional, khususnya kelemahan yang disebabkan tidak adanya tolok ukur dalam penilaian kinerja pemerintah daerah. Pendekatan ini menekankan pada konsep value for money dan pengawasan atas kinerja output sehingga jelas tujuan dan sasaran kinerjanya (Mardiasmo, 2013).

Pemerintah provinsi di Negara Indonesia selama ini belum melakukan pengukuran kinerja dengan menggunakan metode Value for Money. Pengukuran kinerja ini lebih menitikberatkan dalam hal keuangan daerah yaitu Anggaran Pendapatan dan Belanja Daerah (APBD). Diharapkan dengan adanya pengukuran kinerja dengan metode ini, masyarakat secara luas akan lebih mengetahui dan dapat menilai secara fokus tentang bagaimana pemerintah daerah provinsi dalam memanajemen atau mengelola APBD untuk merealisasikan kebijakan berdasarkan pada sasaran yang telah ditentukan, apakah terjadi pemborosan atau tidak, bagaimana hasilnya dengan menggunakan anggaran yang telah ditetapkan, sesuai dengan sasaran awal atau tidak, serta dampak yang dirasakan oleh masyarakat.

Badan Pusat Statistik (BPS) mencatat, pada tahun 2018 pertumbuhan ekonomi nasional mencapai 5,06 persen, mengalami kenaikan dari tahun sebelumnya sebesar 5,01 persen. Sedangkan secara kumulatif, pertumbuhan ekonomi Indonesia mencapai 5,03 persen. Kepala BPS Kecuk Suhariyanto mengungkapkan, secara spasial atau wilayah pertumbuhan ekonomi nasional masih didominasi oleh pulau Jawa dan Sumatera dengan angka pertumbuhan ekonomi 5,51 persen untuk pulau Jawa, dan 4,43 untuk Pulau Sumatera atau di atas rara-rata laju pertumbuhan ekonomi nasional.Penulis ingin mengetahui perbandingan kinerja keuangan pemerintah propinsi di Indonesia terutama pada propinsi di Jawa dan di Sumatera.

\section{B. LANDASAN TEORI DAN PENGEMBANGAN HIPOTESIS}

\section{Anggaran Sektor Publik}

Anggaran sebagai pernyataan estimasi kinerja yang hendak dicapai selama periode waktu tertentu yang dinyatakan dalam ukuran finansial, sedangkan penganggaran adalah proses atau metode untuk 
mempersiapkan suatu anggaran (Mardiasmo, 2012:61).

\section{Anggaran Berbasis Kinerja}

Pengertian anggaran berbasis kinerja menurut pandangan Government Performance Result Act dalam Yuwono, Indrajaya \& Hariyandi (2015: 35) adalah sebagai berikut :

"Performance budgeting is a systematic approach to help government become more responsive to taxpaying public by linking program funding to performance and production."

\section{Anggaran Pendapatan dan Belanja Daerah (APBD)}

APBD merupakan rencana keuangan tahunan pemerintah daerah yang disetujui oleh DPRD dan ditetapkan dengan peraturan daerah. Untuk menyusun APBD, pemerintah terlebih dahulu menyusun Rencana Kerja Pemerintah Daerah yang merupakan penjabaran dari Rencana Pembangunan Jangka Menengah dengan menggunakan rencana Kerja Satuan kerja Perangkat Daerah untuk jangka waktu satu tahun yang mengacu pada Rencana Kerja Pemerintah (Nordiawan, 2006:88).

\section{Kinerja Keuangan}

Arti dari penilaian kinerja menurut Mardiasmo (2002:28) ''yaitu penentuan secara priodik efektifvitas oprasional suatu organisasi, bagianorganisasi, karyawan berdasarkan sasaran, standar, dan kreteria yang telah ditetapkan sebelumnya." Dan menurut keputusan menteri dalam negeri nomor 29 tahun 2002 yang sekarang berubah manjadi permendagri nomor 13 tahun 2006 tentang pedoman pengurusan, pertanggungjawaban dan pengawasan keuangan daerah serta tata cara penyusunan anggaran pendapatan dan belanja daerah, pelaksanaan tata usaha keuangan daerah dan penyusunan perhitungan Anggaran Pendapatan Belanja Daerah (APBD), bahwa tolakukur kinerja merupakan komponen lainya yang harus dikembangkan untuk dasar pengukuran kinerjakeuangan dalam sistem anggaran kinerja.

\section{Kinerja Keuangan Pemerintah Daerah}

Analisa keuangan menurut Halim (2001:127) 'merupakan sebuah usahamengidentifikasi ciri-ciri keuangan berdasarkan laporan keuangan yang tersedia.'Sedangkan pada pasal 4 PP Nomor 58 tahun 2005 tentang Pengelolaan KeuanganDaerah menegaskan bahwa keuangan daerah dikelolah secara tertib, taat padaperaturan perundang-undangan efisien, ekonomis, efektif, transparan, dan bertanggung jawab dengan memperhatikan asas keadilan, kepatuhan, dan manfaatuntuk masyarakat.

\section{Parameter Kinerja Keuangan Pemerintah Daerah}

Penggunaan analisis rasio pada sektor publik khususnya terhadap APBD belum banyak dilakukan, sehingga secara teori belum ada kesepakatan secara bulat mengenai nama dan kaidah pengukurannya.Analisis rasio keuangan pada APBD keuangan pada APBD dilakukandengan membandingkan hasil yang dicapai dari satu periode dibandingkan denganperiode sebelumnya sehingga dapat diketahui bagaimana kecenderungan yangterjadi. Selain itu dapat pula dilakukan dengan cara membandingkan dengan rasiokeuangan yang dimiliki suatu pemerintah daerah tertentu dengan daerah lain yangterdekat maupun yang potensi daerahnya relatif sama untuk dilihat bagaimanarasio keuangan pemerintah daerah tersebut terhadap pemerintah daerah lainnya. 


\section{Kerangka Pikir}

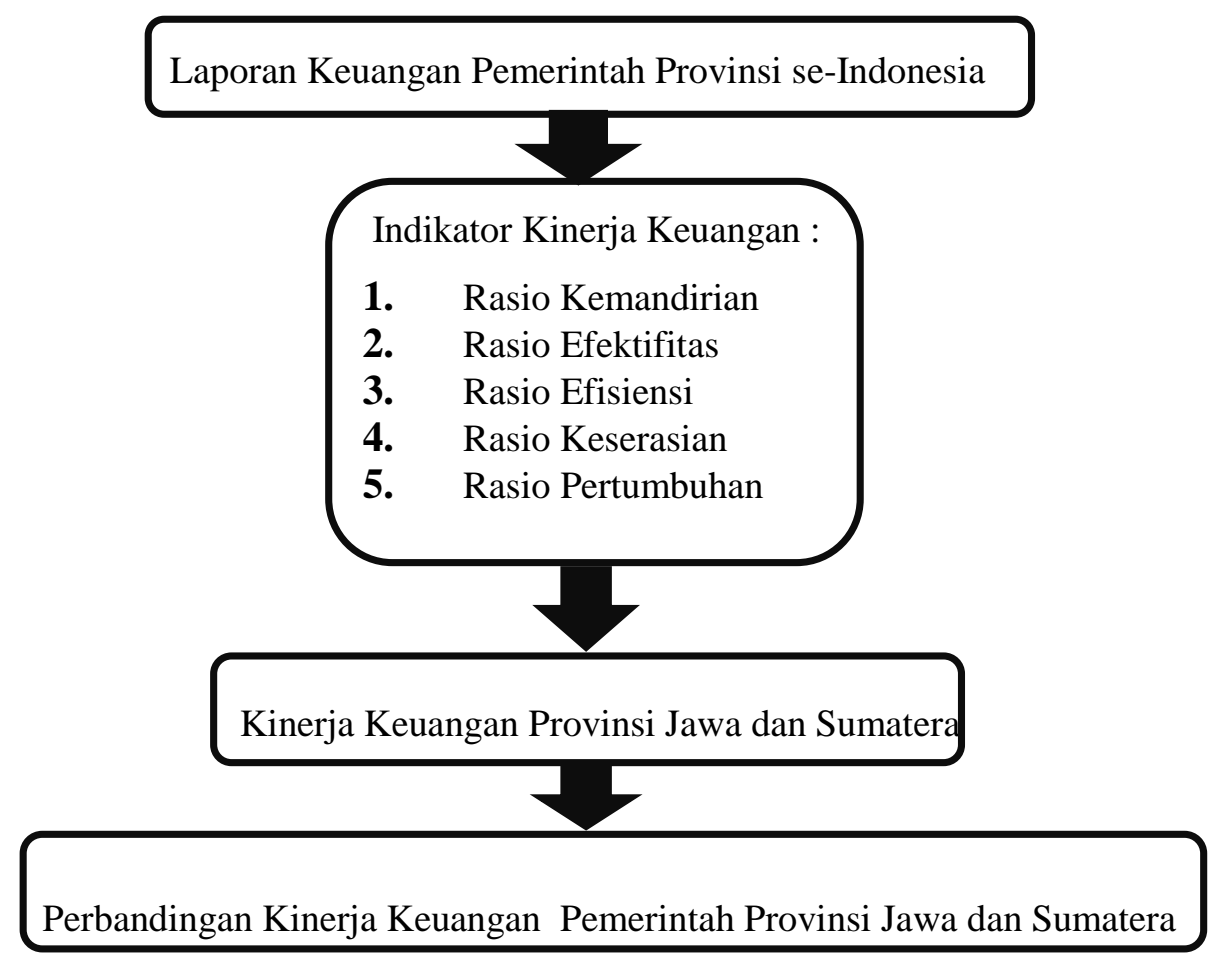

\section{Pengembangan Hipotesis}

Uji Hipotesis yang dilakukan untuk memprediksi kinerja keuangan dan pertumbuhan ekonomi Provinsi yang ada di Indonesia pada tahun-tahun yang akan datang. Perhitungan ini dilakukan dengan membandingkan nilai-nilai variabel berdasarkan nilai anggaran dana pendapatan dan belanja daerah Provinsi se-Indonesia pertahun. Data kuantitatif berupa laporan perhitungan APBD Pemerintah Provinsi di provinsi Jawa dan Sumatera periode anggaran tahun 2014 sampai dengan 2017. Hipotesis yang akan diuji untuk mencapai tujuan penelitian adalah sebagai berikut:

H1:Terdapat perbedaan tingkat kemandirian pada kinerja keuangan pemerintah provinsi di Jawa dan di Sumatera periode 2014-2017.

H2: Terdapat perbedaan tingkat efektivitas pada kinerja keuangan pemerintah provinsi di Jawa dan di Sumatera periode 2014-2017.

H3:Terdapat perbedaan tingkat efisiensi pada kinerja keuangan pemerintah provinsi di Jawa dan di Sumatera periode 2014-2017.

H4:Terdapat perbedaan tingkat aktivitas belanja operasi pada kinerja keuangan provinsi di Jawa dan di Sumatera periode 2014-2017.

H5:Terdapat perbedaan tingkat aktivitas belanja modal / belanja pembangunan pada kinerja keuangan pemerintah provinsi di Jawa dan di Sumatera periode 2014-2017.

H6:Terdapat perbedaan tingkat pertumbuhan PAD pada kinerja keuangan pemerintah provinsi di Jawa dan di Sumatera periode 2014-2017.

\section{METODE PENELITIAN}




\section{Jenis dan Sumber Data}

Data yang digunakan dalam penelitian ini adalah data sekunder. Data sekunder adalah data penelitian yang diperoleh secara tidak langsung melalui media perantara (diperoleh dan dicatat oleh pihak lain). Data sekunder dalam penelitian ini diperoleh dari website/situs resmi Direktorat Jenderal Perimbangan Keuangan dan Badan Pusat Statistik (BPS) mengenai Anggaran Belanja dan Pendapatan Daerah (APBD) dan Laporan Realisasi APBD pemerintah daerah dari provinsi di Jawa dan di Sumatera periode 2014-2017.

Data yang dikumpulkan serta digunakan dalam penelitian ini oleh penulis adalah data sekunder yang merupakan data-data yang diperoleh dari dokumen resmi serta sumber-sumber lainnya yaitu, data Laporan Realisasi Anggaran Pemerintah dan Belanja Daerah (APBD)Provinsi di Jawa dan di Sumatera Tahun 2014-2017.

\section{Metode Pengumpulan Data}

Dalam mendapatkan data yang relevan untuk mendukung analisis pembahasan, penulis mengunakan metode-metode sebagai berikut :

1) Penelitian Lapangan

Penelitian ini digunakan oleh penulis untuk mendapatkan data utama yang akan digunakan untuk melakukan analisis terkait permasalahan yang ingin penulis jawab. Penelitian ini dilakukan dengan cara yaitu :

a. Dokumentasi, yaitu dengan melihat dokumen, catatan dan laporan yang terkait dengan permasalahan yang diteliti sebagai dasar analisis yang akan dilakukan penulis.Metode dokumentasi dilakukan dengan mengumpulkan data-data yang berasal dari dokumen yang sudah ada. Data dalam penelitian ini berasal dari data Anggaran Belanja dan Pendapatan Daerah (APBD) dan Laporan Realisasi APBD pemerintah daerah dari provinsi di Jawa dan di Sumatera periode 2014-2017.

2) Penelitian Kepustakaan

Penelitian kepustakaan dilakukan untuk mendapatkan dasar-dasar mengenai masalah yang diteliti.Penelitian ini dilakukan dengan membaca literatur, majalah dan tulisan ilmiah yang sifatnya mendukung penelitian yang dilakukan peneliti.

\section{Metode Analisa Data}

Analisa data yang dilakukan dengan metode ini adalah:

1. Metode Deskriptif

Metode analisa dengan terlebih dahulu mengumpulkan data yang ada kemudian diklasifikasi, dianalisa, selanjutnya diinterprestasikan sehingga dapat memberikan gambaran yang jelas mengenai keadaan yang diteliti. Dalam hal ini analisa data akan dilakukan dengan menggunakan:

a. Rasio keuangan daerah yang telah disebutkan pada bab sebelumnya.

Rasio keuangan daerah yang digunakan yaitu:

1) Rasio Kemandirian

Menurut Widodo (Halim, 2004 : 284) Kemandirian keuangan daerah atau otonomi fiskal 
menunjukkan kemampuan pemerintah daerah dalam membiayai sendiri kegiatan pemerintahan, pembangunan dan pelayanan kepada masyarakat. Kemandirian keuangan daerah ditunjukkan oleh besar kecilnya pendapatan asli daerah dibandingkan dengan penerimaan daerah.

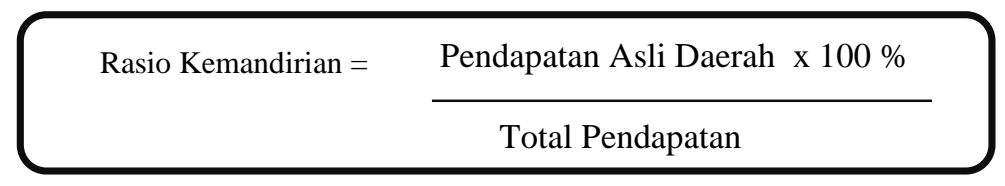

\section{2) Rasio Efektifitas}

Menurut Widodo (Halim, 2004 : 285) Rasio efektifitas PAD menggambarkan kemampuan pemerintah daerah dalam merealisasikan pendapatan asli daerah yang direncanakan dibandingkan dengan target yang ditetapkan berdasarkan potensi riil daerah.

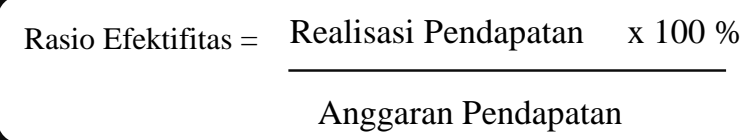

\section{3) Rasio Efisiensi}

Menurut Mahmudin (2007 : 152) rasio efisiensi menggambarkan perbandingan antara besarnya biaya yang dikeluarkan untuk memperoleh pendapatan dengan realisasi pendapatan yang diterima. Kinerja pemerintah daerah dalam melakukan pemungutan pendapatan daerah semakin baik.semakin baik.

$$
\text { Rasio Efisiensi }=\frac{\text { Realisasi Belanja Daerah } \times 100 \%}{\text { Realisasi Pendapatan Daerah }}
$$

\section{4) Rasio Keserasian}

Rasio Keserasian menggambarkan bagaimana pemerintah daerah memprioritaskan alokasi dananya pada Belanja Rutin dan Belanja Pembangunannya secara optimal. Menurut Halim (2012 : 236) semakin tinggi persentase dana yang dialokasikan untuk Belanja Rutin berarti persentase Belanja investasi (Belanja Pembangunan) yang digunakan untuk menyediakan sarana dan prasarana ekonomi masyarakat cenderung semakin kecil. Ada 2 perhitungan dalam Rasio Keserasian ini, yaitu : Rasio Belanja Operasi dan Rasio Belanja Modal.

a. Rasio Belanja Operasi

Rasio ini menginformasikan kepada pembaca laporan mengenai porsi belanja daerah yang dialokasikan untuk Belanja Operasi. Belanja Operasi merupakan belanja yang manfaatnya habis dikonsumsi dalam satu tahun anggaran, sehingga sifatnya jangka pendek dan dalam hal tertentu sifatnya rutin atau berulang. Pada umumya proporsi Belanja Operasi mendominasi total belanja daerah, yaitu antara 60-90\%.

Menurut Mahmudin (2017 : 152) didalam pemerintah daerah dengan tingkat 
pendapatan yang tinggi cenderung memiliki porsi belanja operasi yang lebih tinggi dibandingkan pemerintah daerah yang tingkat pendapatannya rendah. Rasio belanja operasi dirumuskan sebagai berikut :

$$
\text { Rasio Belanja Operasi }=\frac{\text { Total Belanja Operasi }}{\text { Total Belanja Daerah }} \times 100 \%
$$

\section{b. Rasio Belanja Modal}

Berdasarkan rasio ini, pembaca laporan dapat mengetahui porsi belanja daerah yang dialokasikan untuk investasi dengan bentuk belanja modal pada tahun anggaran bersangkutan. Belanja modal memberikan manfaat jangka menegah dan panjang juga bersifat rutin.

Menurut Mahmudin (2007 : 152), pada umumnya proporsi belanja modal degan belanja daerah adalah antara 5-20\%. Rasio belanja modal ini dirumuskan sebagai berikut:

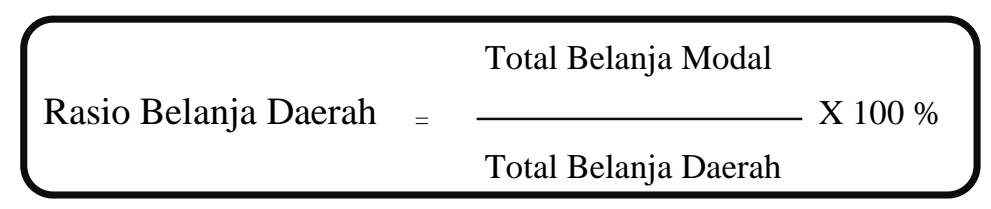

\section{5) Rasio Pertumbuhan}

Rasio pertumbuhan berguna untuk melihat kemampuan atas pengelolaan dimasa yang lalu. Menurut Mahmudi (2010), rasio pertumbuhan bermanfaat untuk mengatahui apakah pemerintah daerah dalam tahun anggaran bersangkutan atau selama beberapa periode anggaran, kinerja anggarannya mengalami pertumbuhan pendapatan atau belanja secara positif atau negatif. Rumus untuk menghitung Rasio Pertumbuhan adalah sebagai berikut :

$$
\mathrm{r}=\frac{\text { Pendapatan Tahun } \mathrm{t}-\text { Pendapatan Tahun }(\mathrm{t}-1) \quad \mathrm{x} 100 \%}{\text { Pendapatan Tahun }(\mathrm{t}-1)}
$$

\section{b. Analisis Uji Beda Kinerja Keuangan}

Data penelitian ini sebelum dilakukan uji statistik terhadap hipotesis, terlebih dahulu dilakukan analisis normalitas data yang bertujuan untuk menentukan metode alat uji hasil penelitian. Analisis ini diperlukan untuk mengetahui apakah data penelitian mempunyai distribusi normal atau tidak. Uji normalitas menggunakan uji Kolmogorov-Smirnov Test. Syarat normal tidaknya data terlihat dari probabilitas signifikansinya. Apabila probabilitas signifikansi $<0,05$ maka data tidak terdistribusi secara normal, sedangkan apabila probabilitas signifikansi > 0.05 maka data terdistribusi normal. Beberapa kemungkinan pilihan alat uji statistik atas hasil penelitian setelah dilakukan uji normalitas adalah: 
1) Uji Kolmogorov Smirnov adalah pengujian lebih dari dua sampel. Asumsi yang digunakan pada uji independent sample t-test:
a) Populasi-populasi yang akan diuji berdistribusi normal
b) Varians dari populasi-populasi tersebut adalah sama (Homogeneity of variance)
c) Sampel tidak berhubungan satu dengan yang lain

Kriteria uji asumsi Homogenitas:
a) Jika signifikan $>0,05$ maka Ho diterima (varian sama)
b) Jika signifikan $<0,05$ maka Ho ditolak (varian berbeda)

Kriteria uji independent sample t-test:
a) Ho diterima apabila signifikansinya $>0,05$
b) Ho ditolak apabila signifikansinya $<0,05$

\section{Populasi dan Sampel Penelitian}

Populasi adalah keseluruhan kelompok orang, peristiwa, atau hal yang ingin peneliti invesitigasi.Adapun populasi penelitian ini adalah Laporan Realisasi Anggaran Pendapatan dan Belanja Daerah Pemerintah Provinsi se-Indonesia. Sedangkan sampel adalah bagian dari populasi yang harus memiliki karakteristik populasi dan sesuai dengan tujuan penelitian. Adapun metode pengambilan sampel yang digunakan peneliti adalah metode purposive sampling yakni pengambilan sampel dengan memperhatikan karakteristik dan kriteria tertentu.Kriteria penarikan sampel diambil dari laporan realisasi anggaran pada pemerintah Provinsi se-Indonesia dari tahun 2014-2017, laporan keuangan pemerintah daerah antara tahun 2014 sampai 2017 telah diperiksa oleh Badan Pemeriksa Keuangan, dan Laporan Hasil Pemeriksaan (LHP) atas laporan keuangan pemerintah daerah tahun 2014 sampai 2017 telah dipublikasikan melalui website resmi BPK.

\section{D.ANALISIS DAN PEMBAHASAN}

Penelitian ini menggunakan data sekunder berupa Laporan Keuangan Pemerintah Daerah (LKPD) tahun 2014-2017, yang diperoleh dari website/ situs resmi Direktorat Jenderal Perimbangan Keuangan dan Badan Pusat Statistik (BPS) mengenai Anggaran Belanja dan Pendapatan Daerah (APBD) dan Laporan Realisasi APBD pemerintah daerah dari provinsi di Jawa dan di Sumatera periode 2014-2017. Elemen yang digunakan dalam Laporan APBD adalah Target Peneriman PAD, sedangkan elemen dalam Laporan Realisasi APBD yang digunakan meliputi Total Pendapatan Daerah, Realisasi Penerimaan PAD, Total Belanja Daerah dan Total Belanja Pelayanan Publik (Belanja Modal), dan pertumbuhan.

\section{Pengujian Hipotesis}

\section{Uji Normalitas}

Sebelum dilakukan uji statistik terhadap hipotesis, terlebih dahulu dilakukan uji normalitas data yang bertujuan untuk menentukan metode alat uji hasil penelitian. Uji normalitas menggunakan Kolmogorov-SmirnovTest. Untuk mendeteksi apakah residual terdistribusi normal atau tidak, dapat dilakukan dengan analisis test normalitu dan uji normal probability plot.

Tabel 1 Hasil uji normalitas data Kolmogorov-Smirnov Test sebagai berikut: 
Tests of Normality

\begin{tabular}{|c|r|r|r|r|r|r|}
\hline \multirow{2}{*}{} & \multicolumn{3}{|c|}{ Kolmogorov-Smirnov ${ }^{\mathrm{a}}$} & \multicolumn{3}{c|}{ Shapiro-Wilk } \\
\cline { 2 - 7 } & Statistic & df & \multicolumn{1}{c|}{ Sig. } & Statistic & \multicolumn{1}{c|}{ df } & Sig. \\
\hline Kinerja_Keuangan & .173 & 16 & $.200^{*}$ & .953 & 16 & .538 \\
\hline
\end{tabular}

a. Lilliefors Significance Correction

*. This is a lower bound of the true significance.

Diketahui bahwa nilai sig adalah sebesar 0,538 artinya nilai sig lebih besar dari 0,05 , dengan demikian maka data dalam penelitian ini terdistribusi normal.

Normal Q-Q Plot of Kinerja_Keuangan

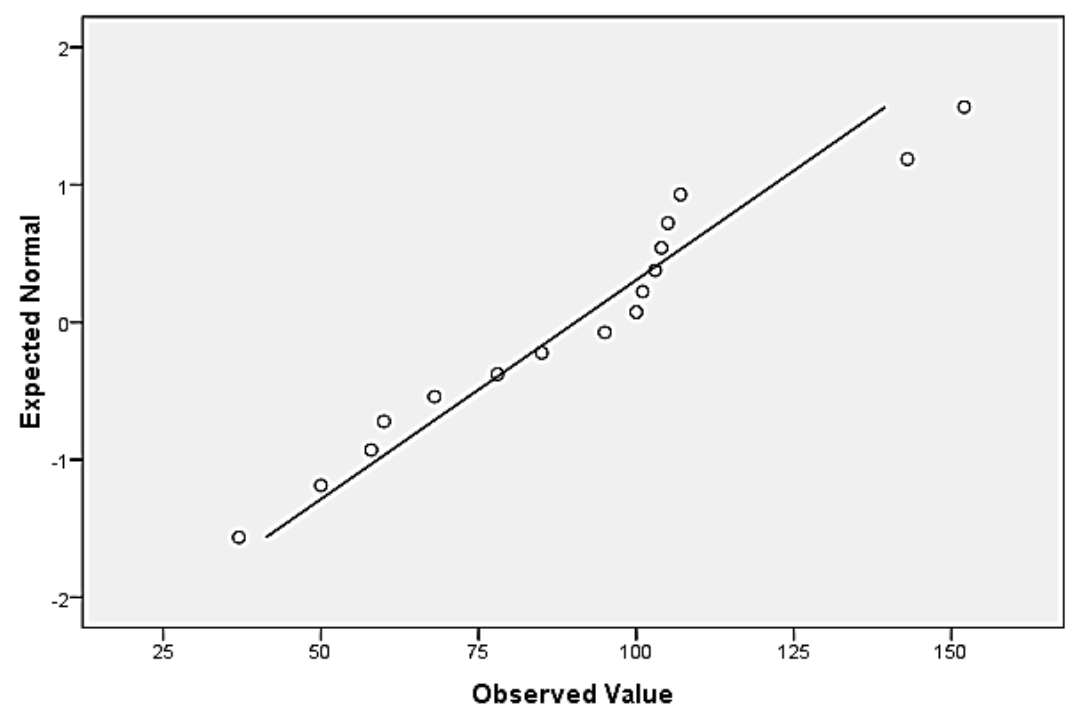

Pada hasil uji normal probability plot yang terdapat pada gambar, terlihat gelembung-gelembung atau titik-titik garis mendekati garis lurus diagonal, seperti yang sudah dijelaskan bahwa distribusi data residual normal maka garis menggambarkan data sesungguhnya akan mengikuti garis diagonalnya. Jadi dapat disimpulkan bahwa data yang digunakan dalam penelitian ini terdistribusi normal.

\section{Uji Beda}

Uji independent sample t-test adalah uji statistik parametrik untuk mengetahui apakah terdapat perbedaan mean antara dua kelompok data yang independent atau tidak terkait. Uji independent sample ttest pada prinsipnya membandingkan rata-rata dari dua group yang tidak berhubungan satu sama lain dengan tujuan apakah kedua group tersebut memiliki rata-rata yang sama atau tidak.

Tabel 1. Hasil Uji Beda Independent Sample t-test

\begin{tabular}{|c|c|c|c|c|}
\hline Rasio & Kelas & Mean & F & Sig. \\
\hline \multirow{2}{*}{ Kemandirian } & Sumatera & $\mathbf{8 9 . 6 0 0 0}$ & \multirow{2}{*}{1.529} & \multirow{2}{*}{0.237} \\
\cline { 2 - 3 } & Jawa & $\mathbf{9 1 . 8 3 3 3}$ & & \\
\hline Efektifitas & Sumatera & 1.0100 & $\mathbf{8 . 9 3 0}$ & $\mathbf{0 . 0 1 0}$ \\
\hline
\end{tabular}




\begin{tabular}{|c|c|c|c|c|}
\hline Rasio & Kelas & Mean & $\mathbf{F}$ & Sig. \\
\hline & Jawa & 1.1333 & & \\
\hline \multirow{2}{*}{ Efisiensi } & Sumatera & 99.1000 & \multirow{2}{*}{0.394} & \multirow{2}{*}{0.540} \\
\hline & Jawa & 98.1667 & & \\
\hline \multirow{2}{*}{ Belanja Operasi } & Sumatera & 73.7000 & \multirow{2}{*}{2.622} & \multirow{2}{*}{0.128} \\
\hline & Jawa & 94.5000 & & \\
\hline \multirow{2}{*}{ Belanja Modal } & Sumatera & 1.0450 & \multirow{2}{*}{0.421} & \multirow{2}{*}{0.527} \\
\hline & Jawa & 1.0383 & & \\
\hline \multirow{2}{*}{ Pertumbuhan } & Sumatera & 7.0000 & \multirow{2}{*}{0.031} & \multirow{2}{*}{0.863} \\
\hline & Jawa & 6.5000 & & \\
\hline
\end{tabular}

Sumber : olah data SPSS V.20, 2019

Berdasarkan hasil analisis uji beda dengan tingkat signifikansi 10\% maka penelitian ini menunjukkan bahwa : rasio kemandirian, rasio efisiensi, rasio belanja operasi, rasio belanja modal, dan rasio pertumbuhan tidak terdapat perbedaan signifikan pada kinerja keuangan pemerintah provinsi di Jawa dan Sumatera. Sedangkan pada rasio efektivitas, diketahui terdapat perbedaan yang signifikan pada kinerja keuangan provinsi di Jawa dan Sumatera.

Dari hasil group statistic, Provinsi di Jawa memiliki kinerja keuangan yang lebih baik dari Provinsi di Sumatera ditinjau dari rasio kemandirian, efektifitas, dan belanja operasi. Sedangkan ditinjau dari rasio efisiensi, belanja modal, dan pertumbuhan, Provinsi Sumatera memiliki kinerja keuangan lebih baik dari Provinsi Jawa.

\section{SIMPULAN DAN SARAN}

\section{Simpulan}

Dilihat dari rasio kemandirian adalah 0,237 yang artinya lebih besar dari 0,05, dengan demikian H1 tidak terdukung yang berartibahwa tidak terdapat perbedaan yang signifikan pada kinerja keuangan pemerintah Provinsi di Jawa dan di Sumatera tahun 2014-2017. Pada uji beda rasio kemandirian group statistics, diketahui Provinsi di Sumatera memiliki nilai mean 89,6000 sedangkan Provinsi di Jawa memiliki nilai mean 91,8333. Artinya, Provinsi di Jawa memiliki kinerja keuangan yang lebih baik dari Provinsi di Sumatera.Kemandirian keuangan daerah Provinsi di Jawa atau otonomi fiskal menunjukkan kemampuan pemerintah daerah dalam membiayai sendiri kegiatan pemerintahan, pembangunan dan pelayanan kepada masyarakat. Kemandirian keuangan daerah ditunjukkan oleh besar kecilnya pendapatan asli daerah dibandingkan dengan penerimaan daerah. Artinya dalam hal ini, pemerintah Provinsi di Jawa memiliki tingkat kemandirian yang cukup baik dibandingkan Provinsi di Sumatera, karena Provinsi di Jawa memiliki kemampuan untuk membiayai sendiri kegiatan pemerintahannya, yang ditandai dengan pendapatan asli daerah yang cukup tinggi.

Dilihat dari rasio efektifitas adalah 0,010 yang artinya lebih kecil dari 0,05, dengan demikian $\mathrm{H} 2$ terdukung, yang berarti bahwa terdapat perbedaan signifikan pada kinerja keuangan pemerintah Provinsi di Jawa dan di Sumatera tahun 2014-2017.Pada uji beda rasio efektifitas group statistics, diketahui Provinsi di Sumatera memiliki nilai mean 1,01 sedangkan Provinsi di Jawa memiliki nilai mean 1,13. 
Artinya, Provinsi di Jawa memiliki kinerja keuangan yang lebih baik dari Provinsi di Sumatera.Rasio efektifitas PAD menggambarkan kemampuan pemerintah daerah dalam merealisasikan pendapatan asli daerah yang direncanakan dibandingkan dengan target yang ditetapkan berdasarkan potensi riil daerah. Dalam hal ini, Provinsi di Jawa memiliki kinerja keuangan yang cukup baik dari segi efektifitas karena Provinsi di Jawa memiliki realisasi pendapatan yang lebih besar daripada target pendapatan yang direncanakan.

Dilihat dari rasio efisiensi adalah 0,540 yang artinya lebih besar dari 0,05, dengan demikian H3 tidak terdukung, yang berarti bahwa terdapat perbedaan signifikan pada kinerja keuangan pemerintah Provinsi di Jawa dan di Sumatera tahun 2014-2017.Pada uji beda rasio efisiensi group statistics, diketahui Provinsi di Sumatera memiliki nilai mean 99,10 sedangkan Provinsi di Jawa memiliki nilai mean 98,16. Artinya, ditinjau dari segi efisiensi, Provinsi di Sumatera memiliki kinerja keuangan yang lebih baik dari Provinsi di Jawa. Rasio efisiensi menggambarkan perbandingan antara besarnya biaya yang dikeluarkan untuk memperoleh pendapatan dengan realisasi pendapatan yang diterima.Dalam hal ini, Provinsi di Jawa memiliki kinerja keuangan yang cukup baik dari segi efisiensi karena Provinsi di Jawa memiliki realisasi pendapatan yang lebih besar daripada biaya yang digunakan untuk memperoleh pendapatan tersebut.

Dilihat dari rasio belanja operasi adalah 0,128 yang artinya lebih besar dari 0,05, dengan demikian H4 tidak terdukung, yang berarti bahwa tidak terdapat perbedaan signifikan pada kinerja keuangan pemerintah Provinsi di Jawa dan di Sumatera tahun 2014-2017.Pada uji beda rasio belanja operasi group statistics, diketahui Provinsi di Sumatera memiliki nilai mean 73,70 sedangkan Provinsi di Jawa memiliki nilai mean 94,50. Artinya, ditinjau dari segi belanja operasi, Provinsi di Jawa memiliki kinerja keuangan yang lebih baik dari Provinsi di Sumatera.Pemerintah daerah dengan tingkat pendapatan yang tinggi cenderung memiliki porsi belanja operasi yang lebih tinggi dibandingkan pemerintah daerah yang tingkat pendapatannya rendah. Dalam hal ini, Provinsi di Jawa memiliki kinerja keuangan yang cukup baik dari segi belanja operasi karena Provinsi di Jawa memiliki tingkat pendapatan yang tinggi.

Dilihat dari rasio belanja modal adalah 0,527 yang artinya lebih besar dari 0,05, dengan demikian H5 tidak terdukung, yang berarti bahwa tidak terdapat perbedaan signifikan pada kinerja keuangan pemerintah Provinsi di Jawa dan di Sumatera tahun 2014-2017.Pada uji beda rasio belanja modal group statistics, diketahui Provinsi di Sumatera memiliki nilai mean 1,045 sedangkan Provinsi di Jawa memiliki nilai mean 1,038. Artinya, ditinjau dari segi belanja modal, Provinsi di Sumatera memiliki kinerja keuangan yang lebih baik dari Provinsi di Jawa.Belanja modal dialokasikan untuk investasi dengan bentuk belanja modal pada tahun anggaran bersangkutan. Dalam hal ini, artinya Provinsi di Sumatera memiliki belanja modal yang cukup tinggi untuk mencapai pertumbuhan yang ditargetkan.

Dilihat dari rasio pertumbuhan adalah 0,863 yang artinya lebih besar dari 0,05, dengan demikian H6 tidak terdukung, yang berarti bahwa tidak terdapat perbedaan signifikan pada kinerja keuangan pemerintah Provinsi di Jawa dan di Sumatera tahun 2014-2017.Pada uji beda rasio pertumbuhan modal group statistics, diketahui Provinsi di Sumatera memiliki nilai mean 7,0 sedangkan Provinsi di Jawa memiliki nilai mean 6,5. Artinya, ditinjau dari segi pertumbuhan, Provinsi di Sumatera memiliki kinerja keuangan yang lebih baik dari Provinsi di Jawa.Rasio Pertumbuhan bermanfaat untuk mengetahui apakah pemerintah daerah dalam tahun anggaran bersangkutan atau selama periode anggaran, Kinerja Keuangan APBD-nya mengalami pertumbuhan secara positif ataukah negatif. Dalam hal ini Pulau Sumatera 
menunjukan kinerja keuangan yang lebih baik dikarenakan Pulau Sumatera mengalami pertumbuhan positif dalam kinerja APBD selama periode tahun 2014-2017.

\section{Saran}

Saran yang ingin penulis berikan dalam penelitian ini yaitu : Bagi pemerintah daerah propinsi seIndonesia diharapkan untuk meningkatkan kinerja keuangan dengan mengoptimalkan sumber daya alam dan sumber daya manusia yang ada untuk meningkatkan kemandirian daerah untuk meningkatkan pertumbuhan ekonomi. Pengukuran kinerja keuangan daerah dengan menggunakan rasio keuangan diharapkan dapat menjadi rekomendasi atas pelaksanaan laporan keuangan sebagai bahan koreksi dan masukan untuk peningkatan peran pemerintah dalam meningkatkan akuntabilitas publik.

Bagi penelitian selanjutnya disarankan untuk menambah periode penelitian, subjek penelitian, danmetode penelitian sebagai alat pengukurannya

\section{REFERENSI}

Abdul, Sabtari. 2015. Analisis Faktor-Faktor Yang Berpengaruh Terhadap Efektivitas Anggaran Berbasis Kinerja (Studi Kasus Pada SKPD Pemerintah Kabupaten Grobogan. Semarang: Jurnal Akuntansi Sektor Publik. Vol.4, No.2:1-10.

Anggraini, Alia. 2016. Penerapan Anggaran Berbasis Kinerja Pada Kabupaten Pemekaran. Palembang: Jurnal Akuntansi Sektor Publik. Vol.2, No.4:16-21.

Anton, M.G. 2016. Penerapan Anggaran Berbasis Kinerja Untuk Menunjang Akuntabilitas Publik Pada

Badan Lingkungan Hidup Kota Manado. Manado: Jurnal Emba. Vol.4, No.3:553-563.

Arif, Bahtiar, dkk. 2002. AkuntansiPemerintahan. Jakarta :SalembaEmpat.

Bastian, Indra.2006. Akuntansi Sektor Publik : Suatu Pengantar. Jakarta : Erlangga.

Cholifah. 2013. Rancangan Model Efektivitas Penggunaan Anggaran Berbasis Kinerja Dinas Pendapatan Daerah Jawa Timur. Surabaya: Jurnal Wiga. Vol.3, No.2:20-30.

Deputi Pengawasan Bidang Penyelengaraan Keuangan Daerah Direktorat Pengawasan Penyelenggaraan

keuangan Daerah Wilayah 3. 2015. PedomanPenyusunanAnggaranBerbasisKinerja (Revisi).

Erlina, Sri Mulyani, 2007. Metodologi Penelitian Bisnis : Untuk Akuntansi dan Manajemen, Cetakan

Pertama. Medan : USU Press.

Garrison, dkk. 2001. AkuntansiManajerial. Jakarata : Salemba Empat.

Halim, Abdul.2004. BungaRampaiManajemenKeuangan Daerah EdisiRevisi.

UPP AMP YKPN.2001.AkuntansiSektorPublik - AkuntansiKeuanganDaerah.Jakarta

:SalembaEmpat.

Hansen dan Mowen. 2006. AkuntansiManajemen. Jakarta :SalembaEmpat.

Indriantoro, Nur, dkk. 2002. MetodologiPenelitianBisnis :UntukAkuntansi Dan Manajemen. Yokyakarta : BPFE.

Kementerian Pendayagunaan Aparatur Negara. 2015. Clean Government dan Good Government Untuk meningkatkan Kinerja Birokrasi Dan Pelayanan Publik. Jakarta: Kemenpan RB 
Kurrohman, Taufik. 2013. Evaluasi Penganggaran Berbasis Kinerja Melalui Kinerja Keuangan Yang Berbasis Value For Money Di Kabupaten/Kota Jawa Timur. Jember: Jurnal Dinamika Akuntansi. Vol.5, No.1:1-11.

Mahmudin.2006.Analisis kinerja keuangan.Malang :Edisi kedua.

Mardiasmo. 2012. Akuntansi Sektor Publik. Yogyakarta : Penerbit Andi.

Nordiawan, Deddi. 2006. Akuntansi Sektor Publik. Jakarta : Salemba Empat.

Sedarmayanti. 2003. Manajemen Sumber Daya Manusia. Reformasi Birokrasi dan Manajemen Pegawai Negeri Sipil, Cetakan Kelima. Bandung : PT Refika Aditama.

Sipayung, Friska. 2009. Balanced Scorecard: Pengukuran Kinerja Perusahaan dan Sistem Manajemen Strategis. Jurnal Manajemen Bisnis, Vol. 2, No.1, Universitas Sumatera Utara, Medan.

Sugiyono. 2007. Metode Penelitian Kuantitatif Kualitatif dan R\&D. Bandung: Alfabeta.

Putra, Erlanda Juliansyah. 2012. Pengelolaan Kepegawaian Pada Era Otonomi. Kanun Jurnal Ilmu Hukum, No. 65, April 2015, hal. 37-60. Aceh: Fakultas Hukum Universitas Syiah Kuala. Yuwono, Sony, dkk. 2015. Penganggaran Sektor Publik, Pedoman Praktis Penyusunan, Pelaksanaan, Dan Pertanggungjawaban APBD (Berbasis Kinerja). JawaTimur: Bayumedia Publishing. 